\title{
A new classification of the Chirostyloidea (Crustacea: Decapoda: Anomura)
}

\author{
KAREEN E. SCHNABEL ${ }^{1} \&$ SHANE T. AHYONG ${ }^{2}$ \\ ${ }^{1}$ National Institute of Water and Atmospheric Research, Private Bag 14901, Kilbirnie, Wellington, New Zealand. \\ E-mail: k.schnabel@niwa.co.nz \\ ${ }^{2}$ Australian Museum, 6 College Street, Sydney, NSW 2010 Australia. E-mail: shane.ahyong@austmus.gov.au
}

\begin{abstract}
The high level classification of the Chirostyloidea Ortmann, 1892, is reviewed. Eumunididae Milne-Edwards \& Bouvier, 1900, is resurrected for two genera formerly placed in the Chirostylidae Ortmann, 1892, Eumunida Smith, 1883, and Pseudomunida Haig, 1979, based on shared characteristics such as the dorsal carapace striation, presence of supraocular spines of the rostrum, dentition of the mandible, presence of an epipod and an annulated exopod flagellum of maxilliped 1. Three families are now included in the Chirostyloidea: Chirostylidae, Eumunididae and Kiwaidae. Diagnoses are provided for each family as well as a key to the families. The fossil record of the Chirostyloidea is discussed, with putative records of Eumunida in the fossil record referred to the galatheid genus Sadayoshia Baba, 1969.
\end{abstract}

Key words: Galatheoidea, Chirostylidae, Eumunididae, Kiwaidae, adult somatic morphology, larval morphology, fossil record

\section{Introduction}

Recent focus on the phylogeny of Anomura has generated significant molecular phylogenetic information that has challenged the traditional understanding of the marine squat lobsters and porcelain crabs, the Galatheoidea, which comprised the Chirostylidae Ortmann, 1892, Galatheidae Samouelle, 1819, Porcellanidae Haworth, 1825, and Kiwaidae Macpherson, Jones \& Segonzac, 2005 (e.g., Ahyong et al. 2009; Bracken et al. 2009). Most importantly, the Galatheoidea have been shown to be polyphyletic, warranting the removal of the Chirostylidae and Kiwaidae to a separate superfamily, Chirostyloidea (Schnabel et al. in press; Ahyong et al. in press).

The family Chirostylidae currently includes seven genera and over 200 species worldwide (Baba 2009; Baba \& Lin 2008; Baba et al. 2008; Schnabel 2009). The chirostylid genera fall into two, apparently natural, groups. One group comprises Chirostylus Ortmann, 1892, Gastroptychus Caullery, 1896, Hapaloptyx Stebbing, 1920, Uroptychodes Baba, 2004, and Uroptychus Henderson, 1888. The second group includes Eumunida Smith, 1883, and Pseudomunida Haig, 1979. These two groups were first recognised by A. MilneEdwards \& Bouvier (1894) based on somatic morphology, who informally named the first 'Diptyciens', which contained Ptychogaster (now Gastroptychus) and Diptychus (now Uroptychus), and the second 'Eumunidiens', for Eumunida. Several new chirostylid genera have been recognized since 1894. Stebbing (1920) described Hapaloptyx for a new species, H. difficilis. Hapaloptyx is poorly known at present, but is most similar to Chirostylus. Haig (1979) erected Pseudomunida for a new species, P. fragilis, a species having close morphological affinities to Eumunida, and corresponding to the 'Eumunidiens' group. Uroptychodes was erected for U. epigaster Baba, 2004, and related species formerly placed in Uroptychus (Baba 2004). Recent studies of sperm and larval morphology also support this distinction between groups (e.g., Clark \& Ng 2008; Guerao et al. 2006; Tudge 1997). Likewise, the two groups appear to have differing life histories, with Eumunida producing small eggs in which larvae hatch at an early stage of development (larvae are not currently known for Pseudomunida). In contrast, species of the remaining chirostylid genera produce large 
eggs with abbreviated development (Clark \& Ng 2008; Pike \& Wear 1969). That two distinct morphological groups exist within Chirostylidae is thus clear, having support from somatic morphology and from what is known of life history. However, the question remains as to whether these groups are sister clades.

Two main hypotheses have been proposed about internal phylogenetic relationships within the Chirostyloidea. Ahyong et al. (2009) and Schnabel et al. (in press), using ribosomal sequences, recovered a chirostyloid clade in which Kiwa, Eumunida and Pseudomunida formed a paraphyletic relationship outside of a robust 'Dypticiens' clade. Among these, Eumunida was strongly supported as close to other chirostylids, but the positions of Kiwa and Pseudomunida were ambiguous owing to low nodal support. Using nuclear protein coding gene sequences, however, Chu et al. (2009) and Tsang et al. (in press) found strong nodal support for a Eumunida + Kiwa clade as sister to the main chirostylid clade (Pseudomunida was not analysed). The results of each of these analyses differ in some details of topology, but the relationships at the well-supported nodes are compatible. Thus, according to all analyses, the Chirostylidae sensu lato are not monophyletic. The sum of evidence indicates that the two chirostylid groups first recognised by A. Milne-Edwards \& Bouvier (1894) form separate clades, of which one, the Eumunidiens group is closer to Kiwaidae than to other chirostylids. Thus, we herein recognise a separate family within the Chirostyloidea, Eumunididae, to accommodate Eumunida and Pseudomunida (Fig. 1).

\section{Material and methods}

Specimens used are deposited in the collections of the Australian Museum (AM), National Institute of Water and Atmospheric Research (NIWA), the National Museum of New Zealand Te Papa Tongarewa (NMNZ) and the Muséum national d'Histoire naturelle, Paris (MNHN). Postorbital carapace length (pcl) is given in millimetres (mm). Drawings were made using a WACOM Intuous3 Graphics Tablet and Adobe Illustrator CS3.

\section{Systematics}

\section{Order Decapoda}

\section{Chirostyloidea Ortmann, 1892}

Diagnosis. Body symmetrical, carapace with or without transverse striae; rostrum variously developed, usually prominent; supraocular spines present or absent. Sternal plastron consisting of sternites 3-7. Thoracic somite 8 without sternal plate. Abdomen well developed, all somites sclerotized, articulating. Tailfan well developed, folded against preceding somite; telson and uropods laminar. Telson transversely divided by suture. Antennal peduncle consisting of 5 articles; acicle present or absent. Mandible with toothed cutting edge. Maxilliped 1 with or without epipod. Pereopod 1 always chelate. Pereopod 2-4 as walking legs. Maxilliped 3 and pereopods without epipods. Gills phyllobranchiate.

Composition. Chirostylidae Ortmann, 1892, Eumunididae A. Milne Edwards \& Bouvier, 1900, Kiwaidae Macpherson, Jones \& Segonzac, 2005.

\section{Key to families of Chirostyloidea}

1. Eyes vestigial. Mandibular cutting edge chitinous. Sternite 3 strongly produced anteriorly to an acute point.

- Eyes well developed. Mandibular cutting edge calcified. Sternite 3 anterior margin not strongly produced anteriorly, transversely sinuous, irregular or obtusely angled.

2. Carapace without transverse striae. Supraocular spines absent. Anterolateral margin of abdominal somite 2 without 
anterolaterally directed spine. Maxilliped 1 without epipod. Male pleopod 1 present Chirostylidae

- Carapace with transverse striae. Supraocular spines present. Anterolateral margin of abdominal somite 2 with prom-

inent, anterolaterally directed spine. Maxilliped 1 with epipod. Male pleopod 1 absent. Eumunididae

\section{Chirostylidae Ortmann, 1892}

(Fig. 2C-F, I-L)

Diptycinés A. Milne-Edwards \& Bouvier, 1894: 296, 312; 1897: 116 [vernacular name, unavailable].

Diptyciens A. Milne-Edwards \& Bouvier, 1894: 299. — Bouvier, 1896: 312 [vernacular name, unavailable].

Diptycinae Bouvier, 1896: 312. — A. Milne-Edwards \& Bouvier, 1899: 71, 87; 1900: 350.

Chirostylidae Ortmann, 1892: 244.

Uroptychidae Alcock, 1901: 236, 278.

Diagnosis. Carapace surface smooth, tuberculate or spinose but without transverse striae, posterolateral margin not distinctly defined or greatly inflated; rostrum variously shaped; supraocular spines absent. Anterolateral margin of abdominal somite 2 without prominent, anterolaterally directed spine. Sternite 3 not strongly produced anteriorly. Eyes well developed. Basal antennular article with distolateral spines. Antennal peduncle consisting of 5 articles; acicle present or absent. Mandibular cutting edge calcified, strongly serrated along its length. Maxilliped 1 without epipod; exopod flagellum present or absent, not annulated. Maxilliped 3 to pereopod 4 each with 2 arthrobranchs (well-developed or vestigial on maxilliped 3). Pereopod 5 with 1 arthrobranch only. Pereopods 2-4 with pleurobranch. Male pleopods 1 and 2 present. Male pleopods 3-5 vestigial or absent.

Type genus. Chirostylus Ortmann, 1892, by original designation.

Composition. Chirostylus Ortmann, 1892, Gastroptychus Caullery, 1896, Hapaloptyx Stebbing, 1920, Uroptychodes Baba, 2004, Uroptychus Henderson, 1888.

Remarks. Pleopods 3-5 are absent in most male chirostylids, but are vestigial in some species of Gastroptychus (e.g., G. rogeri Baba, 2000, and G. investigatoris (Alcock \& Anderson, 1899), K. Baba, pers. com.; AM P53251, G. rogeri).

\section{Eumunididae A. Milne Edwards \& Bouvier, 1900, stat. nov.}

(Fig. 1, 2A, B, G, H)

Eumunidiens A. Milne-Edwards \& Bouvier, 1894: 299, 308, 312. — Bouvier, 1896: 312. — A. Milne-Edwards \& Bouvier, 1897: 8, 116 [vernacular name, unavailable].

Eumunidae A. Milne-Edwards \& Bouvier, 1900: 364.

Diagnosis. Carapace cordiform, elongate, with transverse striae; posterolateral margin entire, not excavated; rostrum spiniform, flanked by mesial and usually also lateral supraocular spines; lateral supraocular spine well developed (Eumunida), minute or obsolete (Pseudomunida). Cervical groove distinct. Basal article of ocular peduncle obscured in dorsal view by rostral and supraocular spines. Anterolateral margin of abdominal somite 2 with prominent anterolaterally directed spine. Sternite 3 anterior margin transversely sinuous or irregular, not strongly produced anteriorly. Eyes well developed. Basal antennular article unarmed. Antennal peduncle consisting of 5 articles; acicle present. Mandibular cutting edge calcified, tridentate, with tooth at either end and single median tooth. Maxilliped 1 with well-developed epipod; exopod flagellum annulated in distal portion. Maxilliped 3 to pereopod 4 each with 2 arthrobranchs (vestigial on maxilliped 3). Pereopod 5 with 1 arthrobranch only. Pereopods 2-4 with pleurobranch. Male pleopod 1 absent. Male pleopod 2 vestigial or absent. Male pleopods 3-5 present or absent.

Type genus. Eumunida Smith, 1883, by monotypy.

Composition. Eumunida Smith, 1883, Pseudomunida Haig, 1979. 
Remarks. The Eumunidiens group of A. Milne-Edwards \& Bouvier, 1894, was used in the vernacular sense and as such is an informal name and not available under the International Code of Zoological Nomenclature (see Ng et al. 2008 for discussion of vernacular names as used by A. Milne-Edwards and Bouvier). However, A. Milne-Edwards \& Bouvier (1900), regarding Eumunida as belonging to a Tribe within the Diptycinae, used the Latinized form, Eumunidae, and thus validated the name. Eumunidae has not since been used. In now recognising a separate family, Eumunididae, for Eumunida and Pseudomunida, we attribute authorship to A. Milne-Edwards \& Bouvier (1900).

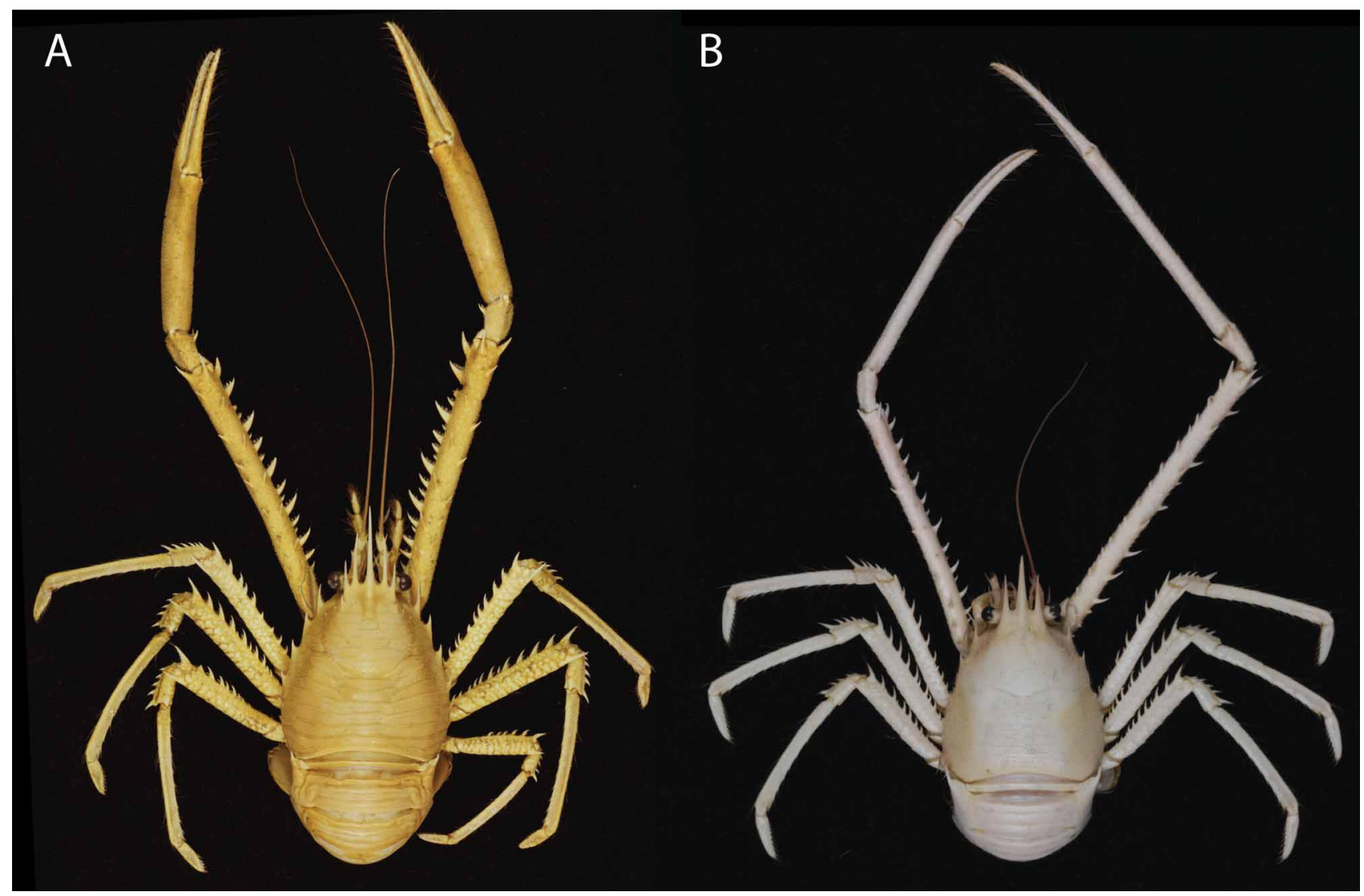

FIGURE 1. Eumunididae: A, Eumunida australis de Saint Laurent \& Macpherson, 1990 (우, pcl 52 mm, NMNZ Cr.5917); B, Pseudomunida fragilis Haig, 1979 (q ovig., pcl 20.5 mm, MNHN-Ga7507).

\section{Kiwaidae Macpherson, Jones \& Segonzac, 2005}

Kiwaidae Macpherson, Jones \& Segonzac, 2005: 712.

Diagnosis. Body elongate, symmetrical. Carapace smooth, without striae. Rostrum well developed, triangular. Cervical grooves clearly distinct; either side of mesogastric region with small, sharply defined pit. Abdominal somites smooth, anterolateral margin of abdominal somite 2 without anterolaterally directed spine with median transverse suture and longitudinal suture in the posterior half of telson. Sternite 3 strongly produced anteriorly to an acute point. Eyes strongly reduced, soft, not calcified, movable, unpigmented. Basal antennular article unarmed. Antennal peduncle consisting of 5 articles; acicle absent. Mandibular cutting edge chitinous, strongly serrated along its length. Maxilliped 1 with well-developed epipod; exopod flagellum not annulated. Cheliped (pereopod 1) with dense corneous spinules along distal portion of occlusal margin. Pereopod 5 inserted below sternite 7, insertion not visible ventrally. Maxilliped 3 to pereopod 4 each with 2 arthrobranchs (vestigial on maxilliped 3). Pereopod 5 without arthrobranch. Pleurobranchs absent. Male pleopods 1-5 present.

Type genus. Kiwa Macpherson, Jones \& Segonzac, 2005, by monotypy.

Composition. Kiwa Macpherson, Jones \& Segonzac, 2005. 


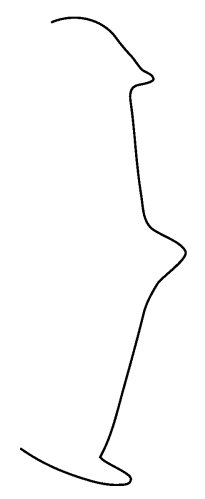

A

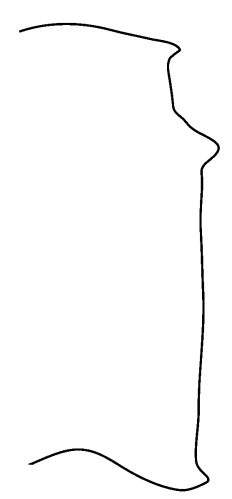

B

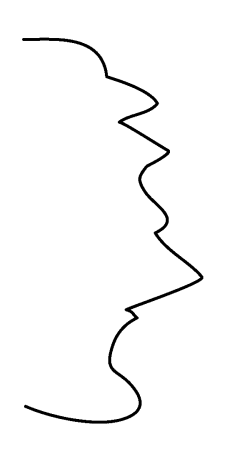

C

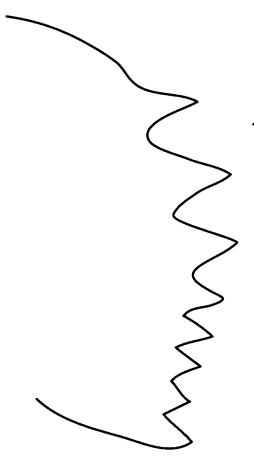

D

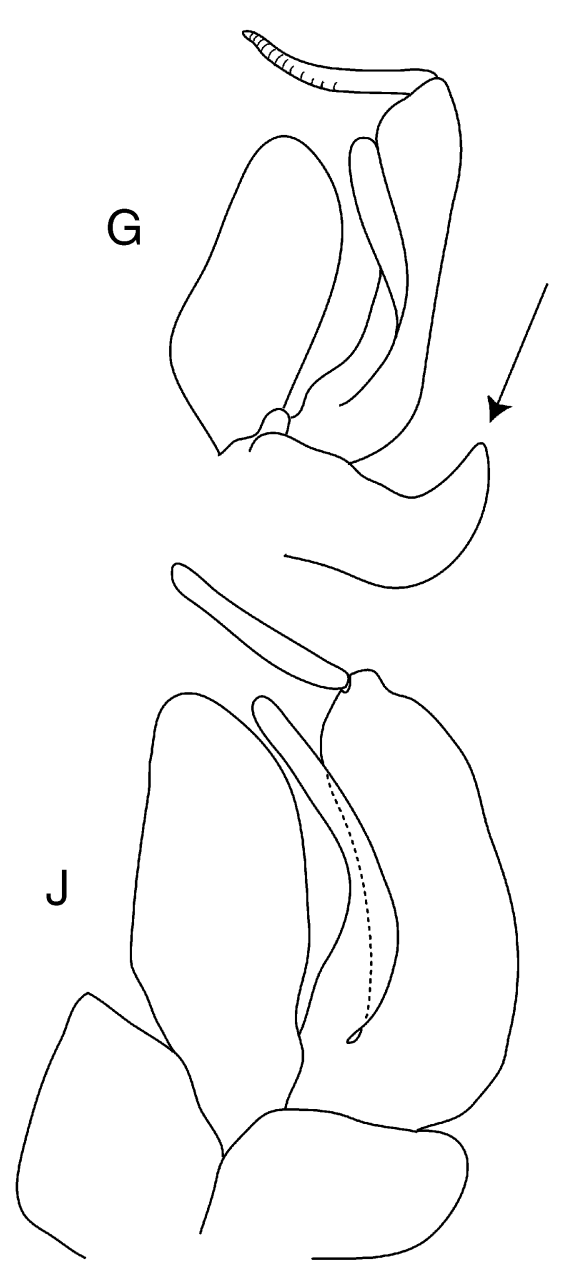

E

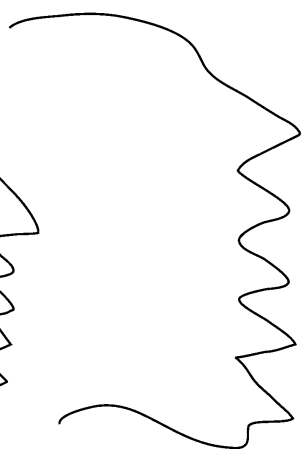

F
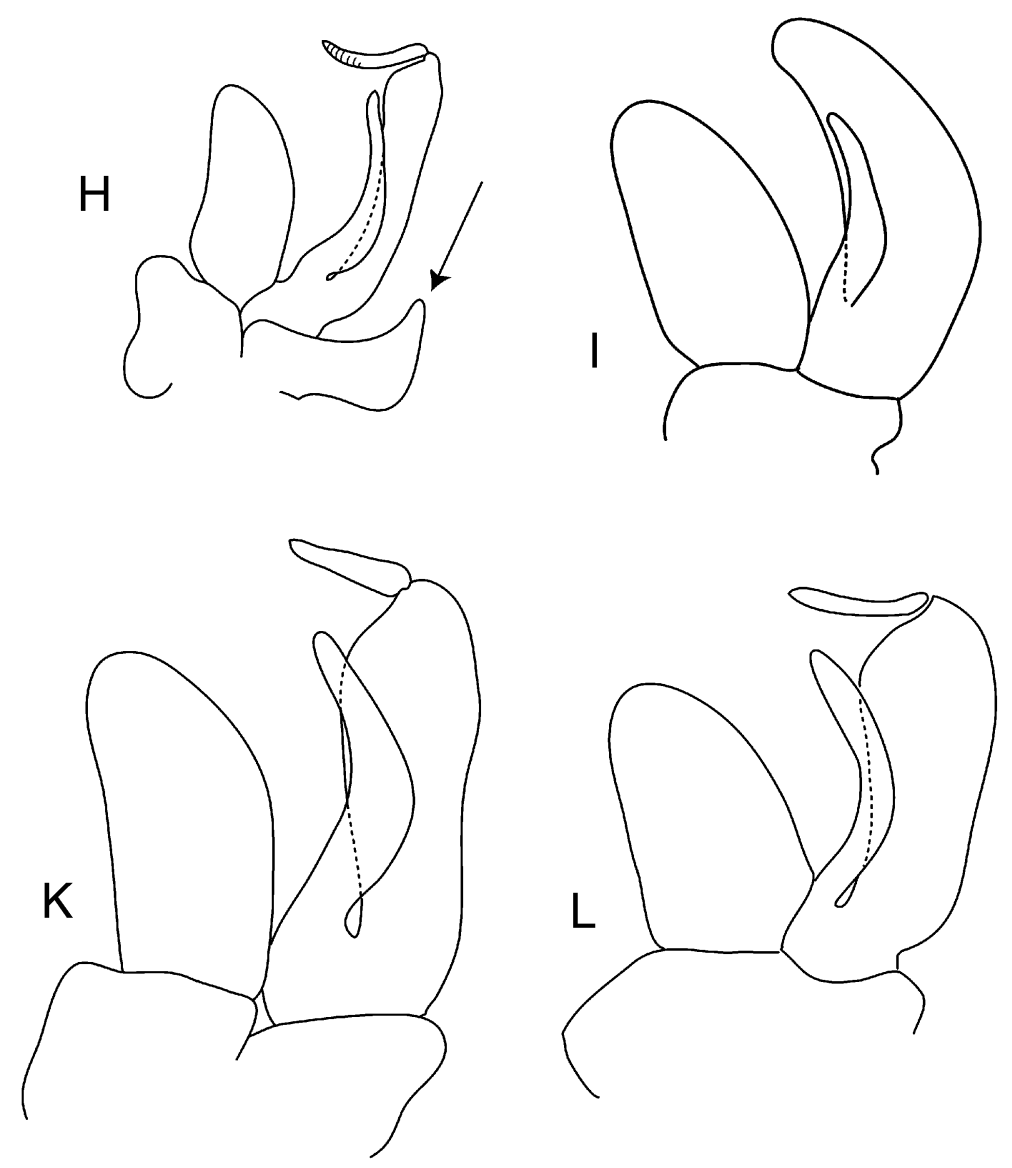

FIGURE 2. A-F, mandibular dentition, ventral view. G-L, right maxilliped 1 endopod and exopod, anterior view

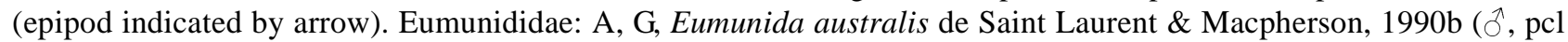
12.9 mm, NMNZ Cr.21765); B, H, Pseudomunida fragilis Haig, 1979 (q ovig., pcl 20.5 mm, MNHN-Ga7507). Chirostylidae: C, I, Chirostylus dolichopus Ortmann, 1892 (o, pcl 2.7 mm, MNHN station LA REUNION, MD32, CP172); D, J, Gastroptychus rogeri Baba, 2000 (ô, pcl 23.2 mm, NIWA 14555); E, K, Uroptychodes epigaster Baba, 2004 (q, pcl 3.4 mm, NMNZ Cr.21766); F, L, Uroptychus cardus Ahyong \& Poore, 2004 (ô, pcl 10.5 mm, NIWA 23086). Scale: A-F, not to scale; G, H, J, L = $1.00 \mathrm{~mm}$;, $\mathrm{K}=0.45 \mathrm{~mm}$. 


\section{Discussion}

The family Eumunididae is readily distinguished morphologically from Chirostylidae sensu stricto in the presence of supraocular spines (absent in Chirostylidae), transverse carapace striae (absent in Chirostylidae), the presence of an epipod on maxilliped 1 (absent in Chirostylidae), unarmed antennular basal article, absence of male gonopods (present in Chirostylidae) and feebly rather than strongly dentate mandible (A. MilneEdwards \& Bouvier 1894; Haig 1979).

In the Chirostylidae sensu stricto, the mandibular cutting edge is strongly dentate along its length (Fig. 2C-F) whereas in the Eumunididae, the cutting edge is smooth apart from three teeth, one at either end, and a third tooth along the margin (Fig. 2A-B). A smooth or unidentate mandibular cutting edge is probably plesiomorphic in Anomura, being shared by most Paguroidea, all Galatheoidea, Hippoidea and the sister group to Anomura, Brachyura. In contrast, a dentate mandible appears to be a synapomorphy uniting Chirostylidae, Kiwaidae, Lomisidae and Aeglidae. As part of the Chirostyloidea, the eumunidids are nested within the chirostyloid + lomisoid + aegloid clade, indicating that the plesiomorphic condition of the mandibular cutting edge in the stem lineage Eumunididae is to be strongly dentate. Thus, the tridentate condition in the crown-group eumunidids, although superficially similar to that of paguroids, galatheoids and hippoids, is a derived state.

The enigmatic Hapaloptyx Stebbing, 1920 (type species H. difficilis Stebbing, 1920), is the only taxon for which we could not confirm morphological details. Hapaloptyx difficilis Stebbing, 1920, was described on the basis of an $8 \mathrm{~mm}$ pcl, disarticulated specimen collected off Natal, South Africa. It was in poor condition at the time of description, and was described as having a non-dentate mandible. According to Stebbing's (1920) figures, the chelipeds more closely resemble those of some majoid crabs than chirostylids, and we suspect that either the type account is inaccurate or that more than one species may comprise the type material. The body and other limbs otherwise correspond well to Chirostylus. Hapaloptyx requires redescription, but is retained in Chirostylidae at present.

The maxilliped 1 of the Eumunididae, in common with that of Kiwaidae, differs from Chirostylidae in having a well-developed epipod (absent in Chirostylidae) and a distally annulate flagellum on the exopod (non-annulate in Chirostylidae) (compare Fig. 2G, H and 2I-L). Note that the original account of Kiwa described the epipod as absent and exopod of maxilliped 1 as bilobed (Macpherson et al. 2005). However, we interpret the proximal lobe of the putative exopod described for Kiwa as the epipod; it corresponds positionally and structurally to the epipod of eumunidids, aeglids, hippoids and pylochelid hermit crabs.

The disposition of pleopods in male Chirostyloidea varies between families, but has not previously been summarized. In Chirostylidae, male pleopods 1 and 2 are present and pleopods 3-5 are vestigial or absent. In Kiwaidae, male pleopods 1-5 are all well developed. In Eumunididae, male pleopod 1 is always absent but the condition of pleopods 2-5 varies. Pleopods 2-5 are always absent in Pseudomunida and all but two species of Eumunida. In male E. parva de Saint Laurent \& Macpherson, 1990a, and E. smithii Henderson, 1885, pleopod 2 is vestigial or absent, respectively, and pleopods 3-5 are all vestigial (Saint Laurent \& Macpherson 1990a; Saint Laurent \& Poupin 1996). The sequence of derivation of the male pleopods in Chirostyloidea is not immediately obvious. Near relatives of the Chirostyloidea (i.e., Aegloidea and Lomisoidea), however, have the following arrangement of male pleopods: in Aegloidea, pleopod 1 is absent and pleopods 2-5 are represented by a minute sclerite, the so-called pleopod remnant (Martin \& Abele 1988), and in Lomisoidea, pleopods 1-2 are well developed, and pleopods 3-5 are minute as in Aeglidae, although not calcified (Pilgrim 1965). Based on these comparisons, loss of pleopods 3-5 appears to be plesiomorphic for Chirostyloidea.

Comparative studies of the sperm morphology of a wide range of anomurans indicated strong differences between representatives of Uroptychus and Eumunida, which also lend more support to the separation of the Chirostylidae and Eumunididae (Tudge 1997; Jamieson \& Tudge 2001). Additionally, sperm characteristics of both taxa examined were more similar to hermit crab sperm morphology than to members of the Galatheidae and Porcellanidae.

Early larval morphology of Eumunida was examined for the first time by Guerao et al. (2006), finding clear differences between the first zoeas of Eumunida and other chirostylids. In particular, the larvae of 
Eumunida did not show abbreviated development as in the other chirostylid genera (Clark \& Ng 2008; Ogawa \& Matsuzaki 1987; Pike \& Wear 1969). As in other chirostylid larvae studied, the larvae of Eumunida were more similar to hermit and mole crab larvae than to those of the Galatheidae (Guerao et al. 2006). Both larval and spermatozoal studies thus support the hypothesis that chirostyloids are more closely related to hermit crabs than to galatheids (Ahyong et al. 2009; Chu et al. 2009; Schnabel et al. in press; Tsang et al. in press).

Pseudomunida, containing only P. fragilis Haig, 1979, is known from the Hawaiian Islands and the tropical western Pacific at 969-1480 m depth. Eumunida currently includes two subgenera, the nominate subgenus, with 17 species, and Eumunidopsis, with 12 species. Twenty-four of the 29 species of Eumunida occur in the western and central Pacific and three species each occur in Atlantic and Indian Ocean, at depths between 92-1320 m (Baba et al. 2008; Baba \& Lin 2008). Notably, numerous records provide evidence of a close association between Eumunida picta Smith, 1883, and the scleractinian coral Lophelia pertusa (Linnaeus, 1758) in the northern Atlantic (Buhl-Mortensen \& Mortensen 2004; Kilgour \& Shirley 2008; Lessard-Pilon et al. 2010).

Although chirostyloids are highly speciose today, they are poorly represented in the fossil record. Schweitzer et al. (2010) listed two fossil species. The single fossil chirostylid, Pristinaspina gelasina Schweitzer \& Feldmann, 2000 may correspond to the Chirostylidae. The second fossil species, Protomunida pentacantha Müller \& Collins, 1991, was originally treated as a galatheid, but transferred to Eumunida by Schweitzer \& Feldmann (2000) based on the five frontal carapace spines (rostrum and two pairs of supraorbitals) and transverse carapace grooves. We suggest, however, that Müller \& Collins' (1991) species is actually a galatheoid in the genus Sadayoshia Baba, 1969, which it closely resembles, not only in the conformation of the frontal spines, but in the presence of five marginal carapace spines behind the cervical groove, presence of a transverse row of epigastric spines, and the series of postcervical spines on the carapace surface (present in several species of Sadayoshia). Sadayoshia pentacantha comb. nov. is known from coral rich Upper Eocene (Priabonian) strata Hungary and Italy, and represents the first appearance of the genus in the fossil record. Thus, at present, the palaeontological record of Chirostylidae is restricted to Pristinaspina gelasina; Eumunididae and Kiwaidae are as yet unknown from fossils.

\section{Acknowledgments}

We gratefully acknowledge Keiji Baba, Peter Castro and Enrique Macpherson for constructive comments on the manuscript. Thanks to Régis Cleva (MNHN) and Rick Webber (NMNZ) for specimen loans. NIWA specimens were collected as part of the research programme "Seamounts: their importance to fisheries and marine ecosystems" (New Zealand Ministry of Fisheries), and during the NORFANZ voyage (TAN0306), a survey of the mid-Tasman Sea sponsored by the National Oceans Office, CSIRO Marine Research, Australia, New Zealand Ministry of Fisheries and NIWA, New Zealand). The research was partially supported by the New Zealand Foundation for Research, Science and Technology (project C01X0502).

\section{References}

Ahyong, S.T., Baba, K., Macpherson, E. \& Poore, G.C.B. (in press) A new classification of the Galatheoidea (Crustacea: Decapoda: Anomura). Zootaxa.

Ahyong, S.T. \& Poore, G.C.B. (2004) The Chirostylidae of southern Australia (Crustacea: Decapoda: Anomura). Zootaxa, 437, 1-88.

Ahyong, S.T., Schnabel, K.E. \& Maas, E.W. (2009) Anomuran phylogeny: new insights from molecular data. In: Martin, J.W., Crandall, K.A. \& Felder, D.L. (Eds.) Decapod Crustacean Phylogenetics. CRC Press, Boca Raton, Florida, pp. 399-414.

Alcock, A. (1901) A descriptive catalogue of the Indian deep-sea Crustacea Decapoda Macrura and Anomala, in the Indian Museum. Being a revised account of the deep-sea species collected by the Royal Indian Marine Survey Ship Investigator. Trustees of the Indian Museum, Calcutta, $286 \mathrm{pp}$.

Alcock, A. \& Anderson, A.R.S. (1899) Natural history notes from H.M. Royal Indian Marine Survey Ship 
"Investigator", Commander T.H. Heming, R.N., commanding. Series III, no. 2. An account of the deep-sea Crustacea dredged during the surveying season of 1897-98. Annals and Magazine of Natural History, series 7, 3, 127.

Baba, K. (1969) Four new genera with their representatives and six new species of the Galatheidae in the collection of the Zoological Laboratory, Kyushu University, with redefinition of the genus Galathea. OHMU. Occasional papers of zoological laboratory. Faculty of Agriculture. Kyushu University, Japan, 2, 1-32.

Baba, K. (2000) Two new species of chirostylids (Decapoda: Anomura: Chirostylidae) from Tasmania. Journal of Crustacean Biology, special number 2, 246-252.

Baba, K. (2004) Uroptychodes, new genus of Chirostylidae (Crustacea: Decapoda: Anomura), with description of three new species. Scientia Marina, 68, 97-116.

Baba, K. (2009) A new species of squat lobster (Decapoda, Anomura, Chirostylidae) from the Philippines and Indonesia. Crustaceana, 82, 795-802.

Baba, K. \& Lin, C.W. (2008) Five new species of chirostylid crustaceans (Crustacea: Decapoda: Anomura: Chirostylidae) from Taiwan. Zootaxa, 1919, 1-24.

Baba, K., Macpherson, E., Poore, G.C.B., Ahyong, S.T., Bermudez, A., Cabezas, P., Lin, C.-W., Nizinski, M., Rodrigues, C. \& Schnabel, K.E. (2008) Catalogue of squat lobsters of the world (Crustacea: Decapoda: Anomura-families Chirostylidae, Galatheidae and Kiwaidae). Zootaxa, 1905, 1-220.

Balss, H. (1957) Decapoda. Dr. H.G. Bronn's Klassen und Ordnungen des Tierreichs, 1, 1505-1672.

Bracken, H. D., Toon, A., Felder, D.L. Martin, J.W., Finley, M., Rasmussen, J., Palero, F. \& Crandall, K.A. (2009) The decapod tree of life: compiling the data and moving toward a consensus of decapod evolution. Arthropod Systematics and Phylogeny, 67(1), 99-116.

Bouvier, E.L. (1896) Sur la famille des Chirostylidae, Ortmann, et sur la classification des Galatheidea [Crust.]. Bulletin de la Société entomologique de France, 65, 307-312.

Buhl-Mortensen, L. \& Mortensen, P.B. (2004) Symbiosis in deep-water corals. Symbiosis, 37, 33-61.

Caullery, M. (1896) Crustaces Schizopodes et Decapodes. In: Koehler, R., Resultats scientifiques de la Campagne du Caudan dans le Golfe de Gascogne, aout-septembre, 1895. Annales de l'Université de Lyons, 26, 365-419, pls 1317.

Chu, K.H., Tsang, L.M., Chan, T.Y. \& Ng, P.K.L. (2009) Decapod phylogeny: what can protein-coding genes tell us? In: Martin, J.W., Crandall, K.A. \& Felder, D.L. (Eds.), Crustacean Issues Vol. 18: Decapod Crustacean Phylogenetics. CRC Press, Bocan Raton, Florida, pp. 89-99.

Clark, P.F. \& Ng, P.K.L. (2008) The lecithotrophic zoea of Chirostylus ortmanni Miyake \& Baba, 1968 (Crustacea: Anomura: Galatheoidea: Chirostylidae) described from laboratory hatched material. Raffles Bulletin of Zoology, 56, 85-94.

Davie, P.J.F. (2002) Crustacea: Malacostraca: Eucarida (Part 2): Decapoda-Anomura, Brachyura. CSIRO Publishing, Melbourne, xiv + $641 \mathrm{pp}$.

Guerao, G., Macpherson, E., Samadi, S., Richer de Forges, B. \& Boisselier, M.-C. (2006) First stage zoeal descriptions of five Galatheoidea species from Western Pacific (Crustacea: Decapoda: Anomura). Zootaxa, 1227, 1-29.

Haig, J. (1979) A new genus and species of Chirostylidae (Decapoda, Anomura, Galatheidea) from the Hawaiian Islands. Crustaceana, 5, 89-94.

Haworth, A.H. (1825) A new binary arrangement of the macrurous Crustacea. The Philosophical Magazine and Journal, $65,183-184$.

Henderson, J.R. (1885) Diagnoses of new species of Galatheidae collected during the "Challenger" expedition. Annals and Magazine of Natural History, series 5, 16, 407-421.

Henderson, J.R. (1888) Report on the Anomura collected by H.M.S. Challenger during the years 1873-76. Report on the Scientific Results of the Voyage of H.M.S. Challenger during the years 1873-76. Zoology, 27, 1-221, 21 pls.

Jamieson, B.G.M. \& Tudge, C. (2001) Crustacea-Decapoda. In: Jamieson, B.G.M. (Ed.), Progress in male gamete ultrastructure and phylogeny. John Wiley \& Sons, Ltd., Chichester, pp. 1-95.

Kilgour, M.J. \& Shirley, T.C. (2008) Eumunida picta S. I. Smith, 1883, and Lophelia pertusa (Linnaeus, 1758): A relationship or just good friends? Crustaceana, 81, 587-593.

Lessard-Pilon, S.A., Podowski, E.L., Cordes, E.E. \& Fisher, C.R. (2010) Megafauna community composition associated with Lophelia pertusa colonies in the Gulf of Mexico. Deep-Sea Research Part II (doi: 10.1016/j.dsr2.2010.05.013).

Macpherson, E., Jones, W.J. \& Segonzac, M. (2005) A new squat lobster family of Galatheoidea (Crustacea, Decapoda, Anomura) from the hydrothermal vents of the Pacific-Antarctic Ridge. Zoosystema, 27, 709-723.

Martin, J.W. \& Abele, L.G. (1988) External morphology of the genus Aegla (Crustacea: Anomura: Aeglidae). Smithsonian Contributions to Zoology, 453, 1-46.

Milne-Edwards, A. \& Bouvier, E.L. (1894) Considerations générales sur la famille des Galathéidés. Annales des Sciences Naturelles, Zoologie, series 7, 16, 191-327, fig. 1-36.

Milne-Edwards, A. \& Bouvier, E.L. (1897) Reports on the results of dredging, under the supervision of Alexander 
Agassiz, in the Gulf of Mexico (1877-78), in the Caribbean Sea (1878-79), and along the Atlantic coast of the United States (1880), by the U. S. Coast Survey steamer "Blake," Lieut.-Com. C.D. Sigsbee, U.S.N., and Commander J.R. Bartlett, U.S.N., commanding. XXXV: Description des Crustacés de la Famille des Galathéidés recueillis pendant l'expédition. Memoirs of the Museum of Comparative Zoology at Harvard College, 19, 5-141.

Milne-Edwards, A. \& Bouvier, E.L. (1899) Crustacés Décapodes provenant des campagnes de l'Hirondelle (supplément) et de la Princesse-Alice (1891-1897). Résultats des Campagnes scientifiques Yacht Albert I Monaco, 13, 1-106.

Milne-Edwards, A. \& Bouvier, E.L. (1900) Crustaces Decapodes. Premiere partie. Brachyures et Anomoures. Expeditions scientifiques du Travailleur et du Talisman, 396 pp., 32 pls.

Müller, P. \& Collins, J.S.H. (1991) Late Eocene coral-associated decapods (Crustacea) from Hungary. Contributions to Tertiary and Quaternary Geology, 28, 47-92.

Ng, P.K.L., Guinot, D. \& Davie, P.J.F. (2008) Systema Brachyuorum: Part 1. An annotated checklist of extant brachyuran crabs of the world. Raffles Bulletin of Zoology, 17, 1-286.

Ogawa, K. \& Matsuzaki, K. (1987) Ecological notes on Chirostylus dolichopus (Anomura: Galatheoidea: Chirostylidae) at Miyake-jima, Japan. Researches on Crustacea, 16, 30-46.

Ortmann, A. (1892) Die Decapoden-Krebse des Strassbuger Museums IV. Die Abteilungen Galatheidea und Paguridea. Zoologische Jahrbücher. Abteilung fuer Systematic Oekologie und Geographie der Tiere, 6, 241-326, pls 11, 12.

Pike, R.B. \& Wear, R.G. (1969) Newly hatched larvae of the genus Gastroptychus and Uroptychus (Crustacea, Decapoda, Galatheidae) from New Zealand waters. Transactions of the Royal Society of New Zealand, Biological Sciences, 11, 189-195.

Pilgrim, R.L.C. (1965) Some features in the morphology of Lomis hirta (Lamarck) (Crustacea: Decapoda) and a discussion of its systematic position and phylogeny. Australian Journal of Zoology, 13, 545-557.

Saint Laurent, M. de \& Macpherson, E. (1990a) Crustacea Decapoda: les genera Eumunida Smith, 1883 (Chirostylidae) dans les eaux néo-calédoniennes. Mémoires du Museum national d'histoire naturelle (Paris), 145, 227-288.

Saint Laurent, M. de \& Macpherson, E. (1990b) Les espèces atlantiques du genre Eumunida Smith, 1880 (Crustacea: Decapoda: Chirostylidae. Journal of Natural History, 24, 647-666.

Saint Laurent, M. de \& Poupin, J. (1996) Crustacea, Anomura: les espèces indo-ouest pacifiques du genre Eumunida Smith, 1883 (Chirostylidae): description de six espèces nouvelles. Mémoires du Muséum national d'Histoire naturelle, Paris, 168, 337-385.

Samouelle, G. (1819) The entomologists' useful compendium; or an introduction to the knowledge of British Insects, comprising the best means of obtaining and preserving them, and a description of the apparatus generally used; together with the genera of Linné, and modern methods of arranging the Classes Crustacea, Myriapoda, spiders, mites and insects, from their affinities and structure, according to the views of Dr. Leach. Also an explanation of the terms used in entomology; a calendar of the times of appearance and usual situations of near 3,000 species of British Insects; with instructions for collecting and fitting up objects for the microscope. Thomas Boys: London, 496 pp., 412 pls.

Schnabel, K.E. (2009) A review of the New Zealand Chirostylidae (Anomura: Galatheoidea) with description of six new species from the Kermadec Islands. Zoological Journal of the Linnean Society, 155, 542-582.

Schnabel, K.E., Ahyong, S.T. \& Maas, E.W. (in press) Galatheoidea are not monophyletic - molecular and morphological phylogeny of the squat lobsters (Decapoda: Anomura) with recognition of a new superfamily. Molecular Phylogenetics and Evolution.

Schweitzer, C.E., Feldmann, R.M., Garassino, A., Karasawa, H. \& Schweigert, G. (2010) Systematic list of fossil decapod crustacean species. Crustaceana Monographs, 10, 1-222.

Smith, S.I. (1883) Preliminary report on the Brachyura and Anomura dredged in deep water off the south coast of New England by the United States Fish Commission in 1880, 1881, and 1882. Proceedings of the United States National Museum, 6, 1-57, pls 1-6.

Stebbing, T.R.R. (1920) South African Crustacea (Part X of S.A. Crustacea, for the Marine Investigations in South Africa). Annals of the South African Museum, 17, 231-272.

Tsang, L.M., Chan, T.Y., Ahyong, S.T. \& Chu, K.H. (in press) Hermit to king, or hermit to all: multiple transitions to crablike forms from hermit crab ancestors. Systematic Biology.

Tudge, C.C. (1997) Phylogeny of the Anomura (Decapoda, Crustacea): Spermatozoa and spermatophore morphological evidence. Contributions to Zoology, 67, 125-141. 